\title{
Judging the Next Emergency: Judicial Review and Individual Rights in Times of Crisis
}

David Cole

Georgetown University Law Center, cole@law.georgetown.edu

Reprinted from Michigan Law Review, August 2003, Vol. 101, No. 8. Copyright 2003 by David Cole.

This paper can be downloaded free of charge from:

https://scholarship.law.georgetown.edu/facpub/69

101 Mich. L. Rev. 2565-2595 (2003)

This open-access article is brought to you by the Georgetown Law Library. Posted with permission of the author. Follow this and additional works at: https://scholarship.law.georgetown.edu/facpub 


\section{GEORGETOWN LAW Faculty Publications}

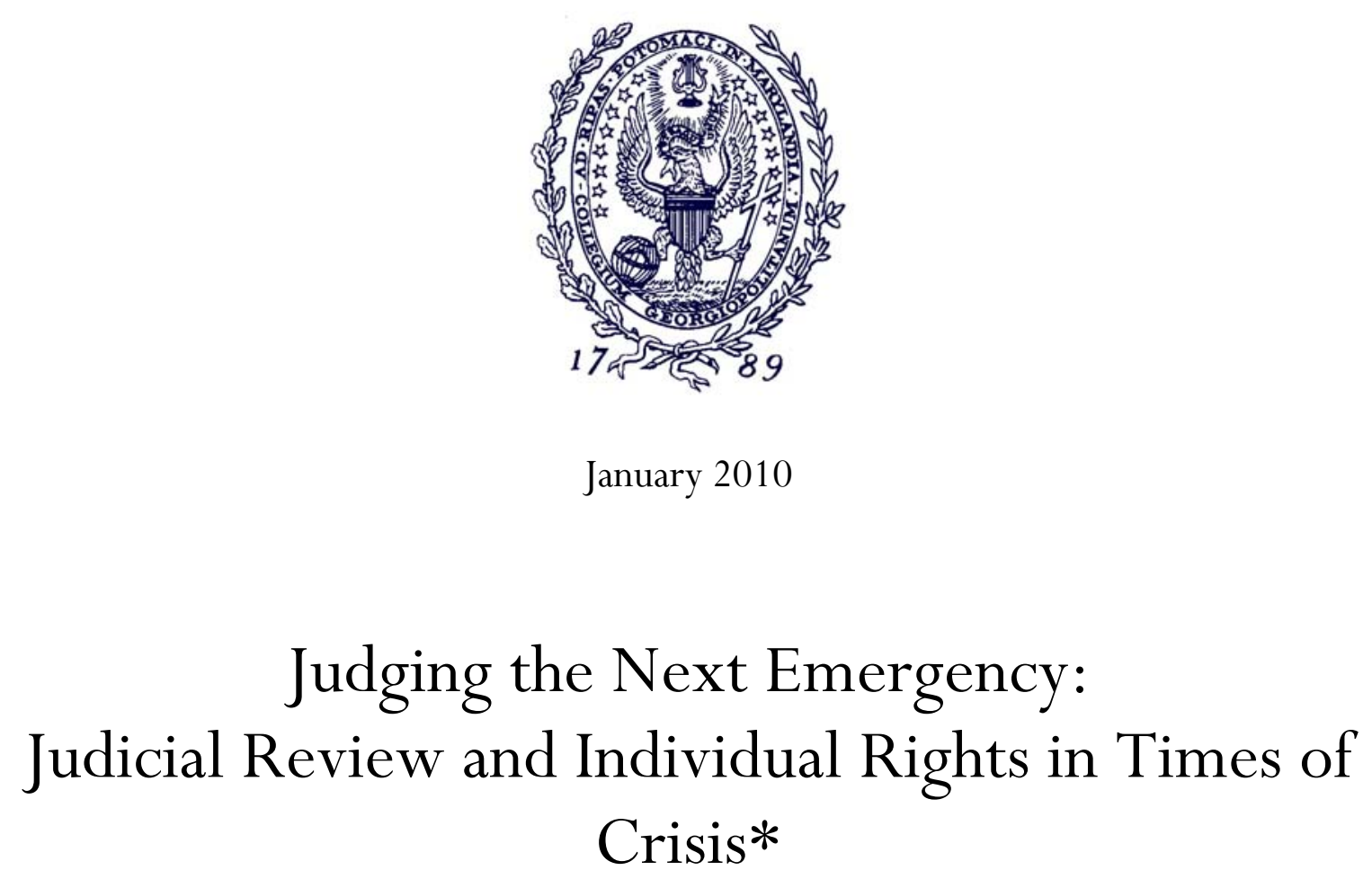

101 Mich. L. Rev. 2565-2595 (2003)

\section{David Cole}

Professor of Law

Georgetown University Law Center cole@law.georgetown.edu

This paper can be downloaded without charge from:

Scholarly Commons: http://scholarship.law.georgetown.edu/facpub/69/

SSRN: $\underline{\text { http: } / / \text { ssrn.com/abstract }=519442}$

Posted with permission of the author

*Reprinted from Michigan Law Review, August 2003, Vol. 101, No. 8. Copyright 2003 by David Cole. 


\title{
JUDGING THE NEXT EMERGENCY: JUDICIAL REVIEW AND INDIVIDUAL RIGHTS IN TIMES OF CRISIS
}

\author{
David Cole*
}

\section{INTRODUCTION}

As virtually every law student who studies Marbury v. Madison ${ }^{1}$ learns, Chief Justice John Marshall's tactical genius was to establish judicial review in a case where the result could not be challenged. As a technical matter, Marbury lost, and the executive branch won. As furious as President Jefferson reportedly was with the decision, there was nothing he could do about it, for there was no mandate to defy. The Court's decision offered no remedy for Marbury himself, whose rights were directly at issue, and whose rights the Court found had indeed been violated. But over time, it became clear that the decision was a landmark victory for those who consider judicial review of political-branch action a critical element of a constitutional system.

Judicial review on matters of national security frequently follows the Marbury model. It rarely provides relief to the individuals before the Court when the national-security crisis is at its height. As in Marbury itself, the challengers generally lose, and the government generally wins. As a result, the conventional wisdom is that courts function poorly as guardians of liberty in times of crisis. Schenck, ${ }^{2}$ Korematsu, ${ }^{3}$ and Dennis, ${ }^{4}$ from World War I, World War II, and the Cold War, respectively, are a few of the more notorious examples. In those cases, the Court authorized the criminalization of speech during World War I, detention based on race during World War II, and guilt by association during the Cold War.

* Professor, Georgetown University Law Center. B.A. 1980, J.D. 1984, Yale University. - Ed. In my capacity as a volunteer staff attorney for the Center for Constitutional Rights, I was co-counsel in some of the cases discussed herein, including North Jersey Media Group, Inc. v. Ashcroft, 308 F.3d 198 (3d Cir. 2002), Haddad v. Ashcroft, 221 F. Supp. 2d 799 (E.D. Mich. 2002), and Humanitarian Law Project v. U.S. Dep't of Justice, No. 02-55082, 2003 U.S. App. LEXIS 24305 (9th Cir. Dec. 3, 2003). My colleague Mark Tushnet provided invaluable feedback, despite his evident disagreement with my position.

1. Marbury v. Madison, 5 U.S. (1 Cranch) 137, 177 (1803).

2. Schenck v. United States, 249 U.S. 47 (1919).

3. Korematsu v. United States, 323 U.S. 214 (1944).

4. Dennis v. United States, 341 U.S. 494 (1951). 
The traditional view, based on these and other examples, holds that judicial review has largely failed to protect individual rights when their protection is most needed. There are good reasons to suspect that this would be so, and, as the examples cited above illustrate, there is plenty of evidence to support the conventional wisdom. But the conventional wisdom is too pessimistic. It is akin to arguing that Marbury demonstrates the weakness of the judiciary because the Court failed to afford Marbury himself relief for the violation of his rights.

Considered over time, judicial review of emergency and nationalsecurity measures can and has established important constraints on the exercise of emergency powers and has restricted the scope of what is acceptable in future emergencies. Because emergency measures frequently last well beyond the de facto end of the emergency, and because the wheels of justice move slowly, courts often have an opportunity to assess the validity of emergency measures after the emergency has passed, when passions have been reduced and reasoned judgment is more attainable. In doing so, courts have at least sometimes been able to take advantage of hindsight to pronounce certain emergency measures invalid for infringing constitutional rights. And because courts, unlike the political branches or the political culture more generally, must explain their reasons in a formal manner that then has precedential authority in future disputes, judicial decisions offer an opportunity to set the terms of the next crisis, even if they often come too late to be of much assistance in the immediate term. Thus, the Court has over time developed a highly protective test for speech advocating illegal activity, ${ }^{5}$ subjected all racial discrimination since Korematsu to exacting scrutiny, ${ }^{6}$ and prohibited guilt by association. ${ }^{7}$ These decisions, among others, impose important limits on what the government can do in the current, post-September 11th crisis.

Since Marbury, scholars have devoted thousands of pages to debating the issue of judicial review, offering critiques of Chief Justice Marshall's reasoning, proposing alternative defenses of judicial review, and, more recently, questioning the value of judicial review altogether. One of the most familiar, and in my view still the strongest, defenses of judicial review is that first advanced in footnote four of Carolene Products, ${ }^{8}$ implemented by the Warren Court and given its definitive academic elaboration in Professor John Hart Ely's Democracy and Distrust. ${ }^{9}$ This is the notion that as an institution insulated from

\footnotetext{
5. Brandenburg v. Ohio, 395 U.S. 444 (1969).

6. See, e.g., Grutter v. Bollinger, 123 S. Ct. 2325 (2003).

7. See, e.g., NAACP v. Claiborne Hardware Co., 458 U.S. 886, 932 (1982).

8. Carolene Prods. v. United States, 304 U.S. 144, 152 n.4 (1944).

9. John HaRT Ely, DEMOCRACY AND Distrust (1980).
} 
everyday politics, the Court is best suited to protect the interests of those who cannot protect themselves through the political process, whether they be members of discrete and insular minorities, dissidents, noncitizens, or other vulnerable individuals. As others have shown, the Court does not always live up to its responsibility. ${ }^{10}$ But it is nonetheless an important ideal to which courts should be held accountable.

How should we judge judicial review from the standpoint of protecting the constitutional rights and liberties of the vulnerable in times of crisis? It is in times of crisis that constitutional rights and liberties are most needed, because the temptation to sacrifice them in the name of national security will be at its most acute. To government officials, civil rights and liberties often appear to be mere obstacles to effective protection of the national interest. As Bush-administration supporters frequently intone when defending their post-September 11th initiatives, "the Constitution is not a suicide pact." Judicial protection is also critical because crisis measures are typically targeted at the most vulnerable among us, especially noncitizens, who have little or no voice in the political process. ${ }^{12}$ We have been in such a crisis period since September 11th and will be for the foreseeable future. So now is a particularly propitious time to assess the value of judicial review in times of crisis. ${ }^{13}$

Part I of this Article will set forth the traditional view that the judiciary is inadequate in times of crisis, along with the evidence that supports it and the reasons that might explain it. Part II maintains that the traditional view overstates the case, because over time judicial decisions have had more of a constraining influence on emergency measures than appears when one looks only at the courts' performance in the midst of a crisis. Part III surveys judicial performance since September 11th on matters of national security and argues that while the record is far from exemplary, courts have actually been more willing to stand up to the government in this period than in many prior crises. Part IV responds to a recent proposal by

10. See, e.g., Gerald N. RosenberG, THE HOLlow HoPe (1991).

11. See, e.g., Bruce Fein, Narrow, Prudent, and Impeccable, WASH. TIMES, Dec. 10, 2002. The quote comes from Kennedy v. Mendoza-Martinez, 372 U.S. 144, 160 (1963).

12. I develop this point in David Cole, ENEMy Aliens: Double STANDARDS AND CONSTITUTIONAL FREEDOMS IN THE WAR ON TERRORISM (2003) [hereinafter COLE, ENEMY ALIENS].

13. I will resist offering broad generalizations about judicial review. Generalizing about judicial review from the standpoint of how courts act in national emergencies is, to me, as invalid as judging the propriety of judicial review on the basis of the Supreme Court's performance in Bush v. Gore, 531 U.S. 98 (2000). The fact that courts, like all other institutions, are susceptible to political pressure in times of high crisis does not warrant a rejection of judicial review in general or of the ideals that animate it. I address only the somewhat more specific question of how judicial review works in emergencies and on matters of national security. 
two leading scholars that courts and the Constitution ought to play less of a role in assessing emergency measures. ${ }^{14}$ Professors Oren Gross and Mark Tushnet have both recently argued that the poor performance of courts during emergency periods and the need for extraordinary emergency powers should impel us to acknowledge explicitly the validity of extraconstitutional emergency measures and leave judgment of such measures to the political rather than the judicial process. In my view, this proposal is fundamentally misguided, both because it fails to acknowledge the valuable role that courts have played, when viewed over time, in constraining emergency powers, and because the alternative of relying on the political process would almost certainly provide even less protection for individual rights than the courts have. To paraphrase Winston Churchill, judicial review is the worst protector of liberty in times of crisis, with the exception of all the others.

\section{THE CONVENTIONAL WisDom}

The conventional wisdom is that courts are ineffective as guardians of liberty when the general public is clamoring for security. Clinton Rossiter, in an influential study of the Supreme Court in wartime, concluded that:

the courts of the United States, from the highest to the lowest, can do nothing to restrain and next to nothing to mitigate an arbitrary presidential military program suspending the liberties of some part of the civilian population.... Whatever relief is afforded, and however ringing the defense of liberty that goes with it, will be precious little and far too late. ${ }^{15}$

Judge Learned Hand similarly concluded that one cannot rely on the courts in times when the people do not fight for their own rights:

I often wonder whether we do not rest our hopes too much upon constitutions, upon laws and upon courts. These are false hopes.... Liberty lies in the hearts of men and women; when it dies there, no constitution, no law, nor court can save it; no constitution, no law, no court can even do much to help it. While it lies there it needs no constitution, no law, no court to save it. ${ }^{16}$

Justice Robert Jackson took this view so far as to advocate in dissent in Korematsu that the civil courts should simply refuse to enforce military orders. Jackson famously wrote:

14. Oren Gross, Chaos and Rules: Should Responses to Violent Crises Always Be Constitutional?, 112 Yale L.J. 1011 (2003); Mark Tushnet, Defending Korematsu?: Reflections on Civil Liberties in Wartime, 2003 WIS. L. REV. 273.

15. Clinton Rossiter \& R. Longaker, The Supreme Court and the COMMANDER-IN-CHIEF 52 (expanded ed. 1976).

16. LEARNEd HAND, THE SPIRIT OF LiBERTY: PAPERS AND AdDRESSES of LEARNED HAND $89-90$ (Irving Dilliard ed., 1960). 
Of course the existence of a military power resting on force, so vagrant, so centralized, so necessarily heedless of the individual, is an inherent threat to liberty. But I would not lead people to rely on this Court for a review that seems to me wholly delusive.... If the people ever let command of the war power fall into irresponsible and unscrupulous hands, the courts wield no power equal to its restraint. The chief restraint upon those who command the physical forces of the country, in the future as in the past, must be their responsibility to the political judgments of their contemporaries and to the moral judgments of history. ${ }^{17}$

Finally, George Bernard Shaw gave the critique his own inimitable flair in offering the following evaluation of the courts during World War I:

[D]uring the war the courts in France, bleeding under German guns, were very severe; the courts in England, hearing but the echoes of those guns, were grossly unjust; but the courts in the United States, knowing naught save censored news of those guns, were stark, staring, raving mad. $^{18}$

There is a wealth of evidence to support this conventional wisdom. During the Civil War, apart from Chief Justice. Taney's ineffectual solo intervention in Ex parte Merryman ${ }^{19}$ - in which he declared invalid President Lincoln's suspension of habeas corpus, only to have Lincoln ignore him - the Supreme Court as a whole largely stayed out of the war. During World War I, the Court failed to overturn a single one of the more than one thousand convictions handed down for speaking out against the war or the draft.$^{20}$ It chose to review only a handful of the convictions, and affirmed them all, most by a unanimous vote. ${ }^{21}$ In World War II, the Court upheld the Japanese internment and unanimously affirmed the military-tribunal convictions of several German saboteurs ${ }^{22}$ with Justice Frankfurter playing a lead role in crafting the majority decision despite having personally played a critical advisory role in creating the tribunals in the first place. ${ }^{23}$ In the early years of the Cold War, as well, the Court either

17. Korematsu v. United States, 323 U.S. 214, 248 (1944) (Jackson, J., dissenting).

18. See Ex parte Starr, 263 F. 145,147 (D. Mont. 1920). Justice Brennan has advanced much the same evaluation. See William J. Brennan, Jr., The Quest to Develop a Jurisprudence of Civil Liberties in Times of Security Crises, 18 ISR. Y.B. HUM. RTS. 11, 11 (1988) ("There is ... a good deal to be embarrassed about, when one reflects on the shabby treatment civil liberties have received in the United States during times of perceived threats to its national security.").

19. 17 F. Cas. 144 (1861) (No. 9487).

20. COLE, ENEMY AliENS, supra note 12, at 12-13.

21. Id.

22. Ex Parte Quirin, 317 U.S. 1 (1942).

23. Melvin I. Urofsky, Inter Arma Silent Leges: Extrajudicial Activity, Patriotism and the Rule of Law, in TOTAL WAR AND THE LAW: THE AMERICAN HOME FRONT IN WORLD WAR II 27 (Daniel R. Ernst \& Victor Jew eds., 2002). 
denied review or affirmed anti-Communist measures, thereby allowing guilt by association to operate largely unchecked. ${ }^{24}$

There are at least four reasons why courts are likely to fare poorly on matters of national security, especially in times of crisis. First, their independence notwithstanding, judges are part of the government and are likely to identify with the government's interests when matters of national security are at stake. The populace as a whole generally rallies around the executive branch in times of crisis, and courts are likely to do so as well. As history has shown, judges cannot stand above the crisis, precisely because the threat at least presumably implicates them as well - both as part of the government and as part of the society.

Second, assessing claims of national security, especially during times of crisis, is inherently difficult, and judges are likely to feel ill-equipped to do so. Most questions of constitutional rights and liberties present a question of balancing. Even the prohibition on race discrimination can be overcome by a sufficiently compelling justification and narrowly tailored means..$^{25}$ But how does one accurately measure the risk that $\mathrm{Al}$ Qaeda might gain critical information enabling it to attack us, or that an individual, if set free, might endanger the national security?

Such decisions must inevitably rest on incomplete information, and the courts' information is often even more incomplete than that of the executive. The executive branch frequently has a monopoly on the information because so much of it is classified, the challengers are often unable to respond, and, absent adversarial testing, it is difficult for a court to know whether the government has been fully candid in its assessment. The Supreme Court's decision in Korematsu, in which it deferred to military claims of necessity as justification for the Japanese internment, was later shown to be based on an inaccurate record; the executive branch concealed from the Court critical information about its own doubts concerning the reality of the threat posed by the Japanese population. Indeed, the executive branch's misrepresentations were so fundamental that years later courts overturned the convictions on writs of coram nobis. ${ }^{26}$

Third, courts must worry that if they rule against the government on a matter of national security, they may face a potential test of their credibility and legitimacy. If the President truly believes that the secu-

24. ARthur J. Sabin, In Calmer Times: The Supreme Court and Red Monday 90-105 (1999); William M. Wiecek, The Legal Foundations of Domestic Anticommunism: The Background of Dennis v. United States, 2001 SUP. CT. REV. 375, 428-34.

25. See, e.g., Grutter v. Bollinger, 123 S. Ct. 2325 (2003).

26. Hirabayashi v. United States, 828 F.2d 591, 604-08 (9th Cir. 1987); Korematsu v. United States, 584 F. Supp. 1406, 1419 (N.D. Cal. 1984). See generally PETER IRONS, JUSTICE AT WAR (1983). 
rity of the nation is at stake, it is entirely possible that he will defy any decision against him. ${ }^{27}$ During the Civil War, for example, when Chief Justice Taney in Ex parte Merryman ${ }^{28}$ ruled that President Lincoln's suspension of the writ of habeas corpus was unconstitutional and granted a writ of habeas corpus, the military refused to produce the petitioner. Justice Taney then issued an attachment for contempt, but the military refused to accept service of that order. President Lincoln simply ignored Justice Taney's decision altogether.

Fourth, and perhaps most significantly, judges must worry that if they rule against the government, their decisions might be followed, at some subsequent cost to national security. Just as no judge wants to be the one who has freed a defendant to commit violent crime again, so no judge wants to issue an order that actually causes serious harm to the national security. And since prognostications about security risks are just that, and one can never really be certain, judges may be inclined to err on the side of caution and the government. At the oral argument before the Third Circuit in North Jersey Media Group $v$. Ashcroft, ${ }^{29}$ a case challenging the constitutionality of the Attorney General's decision to close to the public all immigration proceedings involving hundreds of detainees labeled of "special interest" to the September 11th investigation, Judge Morton Greenberg told the ACLU lawyer arguing the case, "We could make a decision here... and people could die. Lots of people ... I saw the second hit [during the World Trade Center attack of September 11th], and I can't erase it from my mind." ${ }^{30}$

\section{A REVISIONIST VIEW}

While there are undoubtedly good reasons and plenty of evidence to support the conventional wisdom that courts perform poorly on matters of national security, that judgment ultimately rests on too narrow a focus - namely, an assessment of how the courts have performed in the midst of particular crises for the particular litigants before them. When one asks instead what role judicial decisions have played over time in framing the options available to the executive branch in emergency periods, a less pessimistic evaluation is warranted. The Supreme Court's decisions during the waning of emergencies, or after the emergencies have ended, have not infrequently called into question or reversed its earlier rulings and have

27. See Louis Smith, American Democracy and Military POWER 266 (1951).

28. 17 F. Cas. 144 (1861).

29. 308 F.3d 198 (3d Cir. 2002).

30. Arguments Made on Deportation Hearing Regs, PA. L. WKLY, Sept. 23, 2002, at 9 (quoting Judge Greenberg). 
created precedents that impose a degree of restraint on the government's actions during the next emergency.

After the Civil War ended and President Lincoln was buried, for example, the Supreme Court issued Ex parte Milligan ${ }^{31}$ in which it declared that, as long as the civil courts remained open for business, the President did not have constitutional authority to try a United States citizen by military tribunal for allegedly conspiring with the enemy. The Court broadly insisted that the Constitution applies equally in peacetime and wartime:

The Constitution of the United States is a law for rulers and people, equally in war and in peace, and covers with the shield of its protection all classes of men, at all times, and under all circumstances. No doctrine, involving more pernicious consequences, was ever invented by the wit of man than that any of its provisions can be suspended during any of the great exigencies of government. Such a doctrine leads directly to anarchy or depotism, but the theory of necessity on which it is based is false; for the government, within the Constitution, has all the powers granted to it, which are necessary to preserve its existence; as has been happily proved by the result of the great effort to throw off its just authority. ${ }^{32}$

At the close of World War II, the Court decided Duncan $v$. Kohanamoku, ${ }^{33}$ which, like Ex parte Milligan, imposed limits on martial law by invalidating a conviction of a civilian in a military tribunal in Hawaii. The Court reasoned, as in Milligan, that trial by military tribunal was barred as long as the civil courts were open. Notably, however, the Court delayed issuing a decision in Kohanamoku until more than a year after it agreed to hear the case, leading one contemporaneous commentator to speculate that the Court had purposefully waited until it was clear that martial law would not have to be reimposed in Hawaii. ${ }^{34}$

Similarly, while the Court consistently upheld the harsh suppression of antiwar speech during World War $\mathrm{I}^{35}$ it subsequently developed increasingly stronger versions of the "clear and present danger" test for protecting subversive speech. In Yates $v$. United States ${ }^{36}$ decided two and one-half years after Senator Joseph McCarthy had been

31. 71 U.S. (4 Wall.) 2 (1866).

32. Ex parte Milligan, 71 U.S. at 120-21; see also Home Bldg. \& Loan Ass'n v. Blaisdell, 290 U.S. 398, 425-26 (1934) ("[The Constitution's] grants of power to the Federal Government and its limitations of the power of the States were determined in the light of emergency and they are not altered by emergency ... even the war power does not remove constitutional limitations safeguarding essential liberties").

33. 327 U.S. 304 (1946).

34. Edwin CORWIN, TOtal WAR AND THE CONSTITUTION 104-05 (1947).

35. See, e.g., Gilbert v. Minnesota, 254 U.S. 325, 332-33 (1920); Abrams v. United States, 250 U.S. 616, 629 (1919); Frohwerk v. United States, 249 U.S. 204, 209-10 (1919); Schenck v. United States, 249 U.S. 47, 52 (1919).

36. 354 U.S. 298 (1957). 
censured, the Court required the government to prove advocacy of action, not merely advocacy of abstract doctrine. That ruling put an end to the ongoing use of the 1940 Smith Act $^{37}$ to criminalize Communist Party leaders for their advocacy. ${ }^{38}$ Still later, in 1969 , the Court adopted an even more speech-protective test in Brandenburg v. Ohio, holding that speech advocating illegal conduct is constitutionally protected unless it is "directed to inciting or producing imminent lawless action and is likely to incite or produce such action." ${ }^{39}$ That test forecloses virtually any prosecution for speech advocating crime short of an actual conspiracy to commit crime. With these rulings, the Court's First Amendment doctrine now imposes significant limits on the government's ability to restrict speech in times of emergency or as a matter of national security. Thus, even though the Court did little to help antiwar activists Schenck, Debs, Frohwerk, and Abrams during World War $I^{40}$ or to stand up to McCarthyism at its height, the Court ultimately adopted an interpretation of the First Amendment that protects the rights of latter-day Schencks and Communists to speak as they wish, so much so that outright censorship of antiwar speech is no longer a plausible option for the government in wartime.

Supreme Court decisions have also largely barred another common tactic of emergency government - guilt by association. In emergencies, authorities seeking to prevent future harm often resort to guilt by association because it permits the imposition of guilt without proof that an individual has committed a specific violent act. ${ }^{41}$ When the Court in Yates effectively foreclosed prosecutions of Communists under the Smith Act's advocacy provisions, federal prosecutors turned to that statute's "membership" provisions. But in Scales $v$. United States ${ }^{42}$ the Court interpreted the membership provisions to require proof not merely of membership, but of "specific intent" to further the organization's illegal ends. ${ }^{43}$ Driven by concerns that guilt by association violates both the First and Fifth Amendments, the Court ruled that individuals could not be prosecuted for mere membership in the Communist Party, nor even for active membership supporting its lawful ends. Instead, the Court held that the government must prove that an individual's Party activities were specifically

37. Alien Registration Act of 1940, Pub. L. No. 76-670, 54 Stat. 670.

38. See SABIN, supra note 24 , at 169-70 (discussing the effect of the Yates decision).

39. 395 U.S. 444,447 (1969).

40. See supra note 35 .

41. See David Cole, The New McCarthyism: Repeating History in the War on Terrorism, 38 HARV. C.R.-C.L. L. REV. 1, 6-8 (2003) (discussing reliance on guilt by association in preventive law enforcement).

42. 367 U.S. 203 (1961).

43. Scales v. United States, 367 U.S. 203, 220 (1961). 
intended to further criminal conduct - in effect, that he had conspired to commit or support crime. The Court subsequently extended that principle broadly, ruling that absent proof of specific intent, the state could not use association to deny security clearances for work in defense facilities, passports for travel abroad, teaching positions, admission to the bar, or even the use of campus meeting rooms by student groups. ${ }^{44}$ Thus, while the Court did little to block the imposition of guilt by association during the early years of the Cold War, its later decisions stemming from that period largely prohibit that tactic today. ${ }^{45}$

The Vietnam War era also resulted in important judicial decisions limiting or rejecting claims of national security. The Vietnam War did not present the same sort of direct threat to national security that was felt during the World Wars and the Cold War. But it nonetheless prompted substantial government incursions on liberties and also produced two landmark national-security cases, both of which resulted in decisions against the government. In New York Times Co. v. United States, ${ }^{46}$ the Court in 1971 permitted the publication of the Pentagon Papers over the government's claim that disclosure of this secret account of the Vietnam War would harm national security. The

44. See NAACP v. Claiborne Hardware Co., 458 U.S. 886, 932 (1982) (holding membership in NAACP insufficient basis for tort liability absent proof of specific intent); Healy v. James, 408 U.S. 169, 186-87 (1972) (finding association with Students for Democratic Socialism insufficient basis for denying use of campus meeting rooms); United States v. Robel, 389 U.S. 258, 262 (1967) (holding government could not deny Communist Party members security clearances for work in defense facilities absent proof that they had specific intent to further the Party's unlawful ends); Keyishian v. Bd. of Regents, 385 U.S. 589,606 (1967) ("[m]ere knowing membership without a specific intent to further the unlawful aims of an organization is not a constitutionally adequate basis" for barring employment in state university system to Communist Party members); Apatheker v. Sec'y of State, 378 U.S. 500, 514 (1964) (finding Communist Party membership insufficient basis for denying passport).

45. This claim is subject to an important qualification. While the war on terrorism has not thus far led to the direct criminalization of membership per se in political groups, the government has resurrected the tactic of "guilt by association" in the name of cutting off terrorist financing. Under a 1996 antiterrorism statute, it is a crime to provide "material support" to designated "terrorist organizations," without regard to the intent, purpose, or effect of one's support. Antiterrorism and Effective Death Penalty Act of $1996 \S 303(\mathrm{a}), 18$ U.S.C. $\S 2339 \mathrm{~B}$ (2003). Under this statute, it is no defense to show that one's support was in fact intended to support only nonviolent humanitarian activities, nor even to show that one's support was designed to and did in fact reduce a recipient group's reliance on violence. One court of appeals has held that this statute does not violate the prohibition on guilt by association because it punishes not membership per se, but acts of material support. Humanitarian Law Project v. Reno, 205 F.3d 1130 (9th Cir. 2000). In my view, this exalts form over substance. What good is the right of association if one has no right to provide any kind of support to the group with which one associates? See generally David Cole, Hanging with the Wrong Crowd: Of Gangs, Terrorists, and the Right of Association, 1999 SUP. CT. REV. 203. At the same time, the existence of Supreme Court precedents strongly condemning guilt by association preclude punishing membership itself and provide strong arguments against this new version of associational guilt.

46. 403 U.S. 713 (1971). 
following year, in United States v. United States District Court, ${ }^{47}$ the Court held that the Attorney General lacked power under the Constitution to authorize warrantless "domestic security" wiretaps. Both cases reflected a skepticism about claims of national security and executive prerogative, and created significant constraints on the government's ability to enforce secrecy and to conduct searches and wiretaps without probable cause of criminal activity.

The Court's decision in Korematsu provides the most conspicuous counterexample to this more optimistic take on the Court's role in reviewing national-security measures. By the time that case was decided, according to Clinton Rossiter, "the military areas had been disestablished and the relocation centers were being broken up." ${ }^{48}$ Yet the Court upheld the internment by a vote of six to three and has never reversed the decision. Pessimists might well point to Korematsu as an example of a judicial decision having the opposite effect from that which I have been emphasizing - as Justice Jackson warned at the time, Korematsu might well have paved the way for future inroads on civil rights and liberties in times of crisis. ${ }^{49}$ But Korematsu's legacy suggests that Jackson's concern may have been overstated. While the decision has not been formally overruled, eight of the Supreme Court's sitting Justices have said that the case was wrongly decided. ${ }^{50}$ Justice Scalia, perhaps the Court's most conservative member, has compared the decision to Dred Scott. ${ }^{51}$ In short, Korematsu has not proved to be the "loaded weapon" that Justice Jackson feared. To the contrary, it has served as an object lesson in what the Court and the government ought not do in future crises.

Thus, when one takes a longer view of the role of courts in constraining emergency powers, the picture is less bleak than the conventional account admits. While most of the developments discussed above came too late to forestall civil rights and civil liberties violations when they were initially undertaken, they have the prophylactic effect of forestalling the same or similar measures in future emergencies. The judicial process is especially conducive to playing this role for several reasons. First, since emergency powers, and the disputes to which they give rise, tend to outlast the actual emergency, those powers can be reviewed by courts when the worst of the crisis is over.

47. 407 U.S. 232 (1972).

48. Clinton Rossiter \& Richard P. Longaker, The Supreme Court and THE COMMANDER IN CHIEF (1976).

49. Korematsu v. United States, 323 U.S. 214, 246 (1944) (Jackson, J., dissenting) (arguing that the principle underlying the Korematsu decision "lies about like a loaded weapon ready for the hand of any authority that can bring forward a plausible claim of an urgent need").

50. See Cole, ENEMy Aliens, supra note 12 , at $99,261 \mathrm{n} .42$ (citing cases).

51. Stenberg v. Carhart, 530 U.S. 914,953 (2000) (Scalia, J., dissenting). 
Thus, the Court's liberty-protective decisions in Milligan and Kahanamoku came when the wars were effectively over, and the Court's protective decisions from the Cold War period began after McCarthy had been censured and the height of anticommunist fervor had passed. The ability (and obligation) of courts to assess the legality of measures long after they have been adopted means that courts may bring more perspective to the question than those acting in the midst of the emergency.

Second, the fact that legal decisions must offer a statement of reasons that then binds future cases contributes to the judiciary's ability to exert control over the next emergency. The obligation to create and to follow precedent means that judicial decisions are likely to have a longer "shelf life" than those of other branches of government. The lawyers' ability to distinguish the current emergency from prior ones, and the current emergency measure from those previously invalidated, means that the obligation to state reasons is no guarantee of future effectiveness in protecting rights, but precedents do tend to take certain options off the table. The government could not punish antiwar speech today, for example.

Third, the common-law method facilitates a measured development of rules in the context of specific cases and permits the incorporation of lessons learned from the early and often most overreactive stages of emergencies. Once those lessons are learned and instantiated in Supreme Court decisions, they play an important role in precluding certain measures that were part of the government's arsenal in the prior emergency. In this sense, just as in Marbury, the Court's emergency-powers decisions may not help the parties immediately before it at the height of the controversy, but in the long run these decisions establish principles that are critical to checking future government abuse.

Fourth, the formalities of the judicial process mandate the creation of an official record that may facilitate reaching a just result. The conviction in Korematsu was ultimately overturned on a writ of coram nobis because Korematsu was able to show, through access to government records, that the Justice Department had misled the courts about the strength of the evidence underlying its national-security concerns. As the warrant requirement demonstrates, record-keeping requirements permit evaluation of government actions after the fact. While judicial proceedings are not necessary to impose record-keeping requirements, the highly formalized judicial process itself creates a record that may make subsequent assessments, beyond the heat of the moment, more reliable.

Fifth, and perhaps most important, federal courts are independent of the political process, and their institutional self-definition turns in significant part on that independence, especially when it comes to the interpretation and enforcement of constitutional rights. As a result, 
they are better suited to entertain claims challenging executive action than are Congress or the executive branch itself, and more likely to take politically unpopular positions than the political branches. While, as noted above, judges, like other government officials, are likely to defer to the executive branch on matters of national security, complete deference is likely to clash with their understanding of their role as judges.

To be sure, judicial decisions are not the only forces that may constrain government actors in the next emergency. Developing cultural norms may also play a role. As noted above, Korematsu has never been formally overruled, but it is nonetheless highly unlikely that anything on the scale of the Japanese internment would happen again. The cultural condemnation of that initiative, reflected in Congress's issuance of a formal apology and restitution, ${ }^{52}$ has been so powerful that the option is a nonstarter even without controlling Supreme Court law. But even here, the legislative apology followed judicial decisions nullifying the convictions on writs of coram nobis. ${ }^{53}$ In addition, the formal requirements that judges give reasons that are binding on future judges means that judicial decisions are likely to play a more specific constraining function than the development of cultural norms. Indeed, John Finn has argued that the obligation to give reasons is constitutive of constitutionalism and underscores the necessity of judicial review to any meaningful system of constitutional law. ${ }^{54}$ Cultural norms and political initiatives are rarely as clear-cut as a legal prohibition, and their very contestability means that they are likely to exert less restraining force than a judicial holding. Court decisions are, of course, also contestable, but generally along a narrower range of alternatives.

Thus, the conventional wisdom that courts perform poorly in crises should be qualified by the important proviso that, when viewed over time, judicial decisions do exert a constraining effect on what the government may do in the next emergency.

\section{SEPTEMBER 11TH AND THE COURTS}

How have the courts fared since September 11th? As Judge Greenberg's comments at the oral argument in North Jersey Media Group illustrate, ${ }^{55}$ the attacks of that day and the threat of future

52. See Civil Liberties Act of 1988, Pub. L. No. 100-383, 102 Stat. 903.

53. See supra note 26.

54. John E. Finn, Constitutions in CRisis: POlitiCAL ViolenCE AND THE RULE OF LAW 33 (1991) ("Some type of constitutional review is a constitutive element of constitutionalism, for the activity of review, the very possibility of review, is predicated upon the necessity to produce reasons in support of action taken.").

55. See Arguments Made on Deportation Hearing Regs, supra note 30. 
catastrophes place tremendous pressure on judges. Nonetheless, a surprising number of judicial decisions initially upheld claims of constitutional rights against official antiterrorist measures. As time went on, the picture began to look more familiar, as courts increasingly deferred to government claims of national security. As of this writing, the Supreme Court has yet to weigh in, and therefore all judgments are necessarily preliminary.

Nonetheless, given the history of judicial deference in times of crisis, the early decisions were quite stunning. In Center for National Security Studies $v$. United States Department of Justice, ${ }^{56}$ a federal district court ruled that the Justice Department's secret arrests of hundreds of persons detained in a preventive detention campaign after September 11th violated the Freedom of Information Act ("FOIA"), and ordered the government to disclose the detainees' names.

In several cases challenging the government's related practice of closing to the public all immigration proceedings involving detainees connected to the September 11th investigations, two district courts ruled that this practice violated the First Amendment right of access of the public, ${ }^{57}$ and one court ruled that it also violated a detainee's Fifth Amendment due process right to a public hearing. ${ }^{58}$ The United States Court of Appeals for the Sixth Circuit unanimously affirmed one of the First Amendment rulings, writing that "democracies die behind closed doors." $" 59$

A federal district judge in New York reviewing the government's treatment of a September 11th suspect, Osama Awadallah, issued a pair of rulings lambasting the government's tactics. ${ }^{60}$ The judge ruled that the government had abused the "material witness" statute ${ }^{61}$ by employing it to hold a witness for a grand jury proceeding rather than for a criminal trial, had lied to obtain the material witness warrant, and had physically abused Awadallah while in custody. The court dismissed all charges against Awadallah, and ordered his release.

A district court ruled in October 2001 that a federal statute making it a crime to provide "personnel" and "training" to designated "foreign terrorist organizations" ${ }^{62}$ was unconstitutionally vague, reasoning

56. 215 F. Supp. 2 d 94 (D.D.C. 2002), modified, 331 F.3d 918 (D.C. Cir. 2003).

57. Detroit Free Press v. Ashcroft, 195 F. Supp. 2d 948 (E.D. Mich. 2002), aff d, 303 F.3d 681 (6th Cir. 2002); N. Jersey Media Group v. Ashcroft, 205 F. Supp. 2d 288 (D.N.J. 2002), rev'd, 308 F.3d 198 (3d Cir. 2002).

58. Haddad v. Ashcroft, 221 F. Supp. 2d 799 (E.D. Mich. 2002).

59. Detroit Free Press v. Ashcroft, 303 F.3d 681 (6th Cir. 2002).

60. United States v. Awadallah, 202 F. Supp. 2d 55 (S.D.N.Y. 2002), rev'd, 349 F.3d 42 (2d Cir. 2003); United States v. Awadallah, 202 F. Supp. 2d 82 (S.D.N.Y. 2002), rev'd, 349 F.3d 42 (2d Cir. 2003).

61. 18 U.S.C. $\$ 3144(2000)$.

62. 18 U.S.C. $\$ 2339 \mathrm{~B}(2000)$. 
that these terms appear to prohibit clearly protected First Amendment activity on behalf of disfavored organizations. ${ }^{63}$ In December 2003, the Court of Appeals for the Ninth Circuit unanimously affirmed that decision and also ruled, by a two to one vote, that in order to satisfy due process, a mens rea requirement must be read into the material support statute. ${ }^{64}$ In January 2004, a district court in a related case declared unconstitutional a USA PATRIOT Act provision criminalizing the provision of "expert advice and assistance" to terrorist groups. ${ }^{65}$ These provisions have proved to be the linchpin of the government's domestic war on terrorism. ${ }^{66}$ In August 2003, another federal judge declared unconstitutional the ban on providing "personnel" and "communications" to terrorist organizations, in one of the Justice Department's most highly publicized post-September 11th antiterrorist prosecutions, against the lawyer and translators for Sheikh Omar Abdel Rahman. ${ }^{67}$

In May 2002, the federal judges authorized to issue warrants for searches and electronic wiretaps under the Foreign Intelligence Surveillance Act ("FISA") ${ }^{68}$ sitting as one court, ruled that the minimization provisions of that statute barred criminal prosecutors from directing foreign intelligence investigations and applications for warrants. ${ }^{69}$ The court cited numerous problems it had experienced under the statute, including the fact that the government had on seventy-five prior occasions provided the court with misleading or inaccurate information. ${ }^{70}$

The district courts hearing challenges to the detentions of American citizens Yaser Hamdi and Jose Padilla, who were being held as "enemy combatants," also rejected sweeping assertions that the detainees had no right to see a lawyer or to obtain judicial review of their detentions. In Hamdi, District Judge Robert G. Doumar rejected the government's position that habeas corpus review was unavailable, insisted that judicial review was required, and sharply dismissed the

63. Humanitarian Law Project v. Reno, No. CV 98-1971 ABC (BQRx), 2001 U.S. Dist. LEXIS 16729 (C.D. Cal. Oct. 3, 2001), modified sub nom. Humanitarian Law Project v. U.S. Dep't of Justice, No. 02-55082, 2003 U.S. App. LEXIS 24305 (9th Cir. Dec. 3, 2003).

64. Humanitarian Law Project v. U.S. Dep't of Justice, No. 02-55082, 2003 U.S. App. LEXIS 24305 (9th Cir. Dec. 3, 2003).

65. Humanitarian Law Project v. Ashcroft, No. CV-03-6107, 2004 U.S. Dist. LEXIS 926 (U.S. Jan. 22, 2004).

66. See COLE, ENEMy ALIENS, supra note 12, at 75-76, 256 n.11.

67. United States v. Sattar, No. 02 Cr. 395 (JGK), 2003 U.S. Dist. LEXIS 12531 (S.D.N.Y. July 22, 2003).

68. 50 U.S.C. $\$ \S 1801-1863(2000)$.

69. In re All Matters Submitted to the Foreign Intelligence Surveillance Court, $218 \mathrm{~F}$. Supp. 2d 611 (U.S. Foreign Intelligence Surveillance Ct. 2002).

70. $1 d$. at 620 . 
government's submission of a two-page declaration from a government bureaucrat based on unidentified hearsay as insufficient to establish the propriety of detaining Hamdi. ${ }^{71}$ In an early appeal, the United States Court of Appeals for the Fourth Circuit, the most conservative federal appellate court in the nation, similarly rejected the government's "sweeping contention" that the President could, without judicial review, designate citizens as enemy combatants and hold them indefinitely. ${ }^{72}$

The district court hearing a habeas action on behalf of Padilla similarly ruled that it could review the legality of the detention. And over strong objections from the military, the court also ordered that Padilla, who has been held incommunicado, must be granted access to his attorney for purposes of challenging his detention. ${ }^{73}$ On appeal, the U.S. Court of Appeals for the Second Circuit went even further, ruling that the President lacked any authority to hold citizens as enemy combatants absent express authorization from Congress. ${ }^{74}$

In December 2003, the United States Court of Appeals for the Ninth Circuit ruled that the foreign nationals held as enemy combatants in Guantanamo Bay, Cuba, have a right to seek habeas corpus review in federal court of the legality of their detentions. ${ }^{75}$ Several other lower courts had previously held to the contrary, but in November 2003, the Supreme Court granted review of two such lower court decisions over the opposition of the executive branch. ${ }^{76}$ In January 2004, the Court also agreed to hear Yaser Hamdi's claims that he was being held unlawfully as an enemy combatant, again over the opposition of the executive branch, which had urged the Court to deny certiorari. ${ }^{77}$ Thus, in an area where the administration initially asserted unilateral authority to detain, unreviewable by the courts, the Supreme Court has now agreed to exercise review. What that review will consist of remains to be seen, of course. But the very fact that the Court agreed to hear the cases over the executive branch's opposition is significant.

71. Hamdi v. Rumsfeld, 243 F. Supp. 2 d 527 (E.D. Va. 2002), rev'd, 316 F.3d 450 (4th Cir. 2002).

72. Hamdi v. Rumsfeld, 296 F.3d 278, 283 (4th Cir. 2002).

73. Padilla v. Bush, 233 F. Supp. 2d 564 (S.D.N.Y. 2002); see also Padilla v. Rumsfeld, 243 F. Supp. 2d 42 (S.D.N.Y. 2003) (reaffirming earlier decision and denying motion for reconsideration).

74. Padilla v. Rumsfeld, 352 F.3d 695 (2d Cir. 2003). 2003).

75. Gherebi v. Bush, No. 03-55785, 2003 U.S. App. LEXIS 25625 (9th Cir. Dec. 18,

76. Al Odah v. United States, No. 03-343, 124 S. Ct. 534, 2003 WL 22070725 (U.S. Nov. 10,2003 ) (granting certiorari).

77. Hamdi v. Rumsfeld, No. 03-6696, 124 S. Ct. 981, 2004 WL 42546 (U.S. Jan. 9, 2004) (granting certiorari). 
In two of the most prominent prosecutions in the war on terrorism, those charging French citizen Zacarias Moussaoui with involvement in the September 11th conspiracy and American citizen John Walker Lindh with aiding Al Qaeda and conspiring to kill Americans, federal courts ruled, again over strenuous objections from the government, that the defendants must be granted access to enemy combatant detainees who allegedly had exculpatory evidence about the defendants. ${ }^{78}$ Shortly after the district court in the Lindh case issued that ruling, the government agreed to drop all terrorism charges in exchange for a plea of guilty to a lesser charge..$^{79}$ In the Moussaoui case, the government has appealed the district court's ruling and has suggested that if it does not prevail, it may remove Moussaoui's case from the criminal process to a military tribunal. ${ }^{80}$

Four federal judges have declared unconstitutional a regulation issued shortly after September 11th that gives immigration "prosecutors," or district directors, the power to keep a foreign national in custody when the immigration judge presiding over the case has found no basis for detention and ordered release on bond. ${ }^{81}$ All four courts found that the regulation violated due process by permitting preventive detention where no showing of flight risk or danger to the community had been made.

These decisions suggest an increasing willingness on the part of judges to question broad assertions of national security. At the same time, other decisions, including subsequent decisions in several of the same cases, fit the more traditional model of deference. The Court of Appeals for the Third Circuit upheld the blanket closure of immigration hearings, ${ }^{82}$ and the Supreme Court denied a petition for certiorari. ${ }^{83}$ A specially convened court of appeals, after entertaining a one-sided secret appeal by the government, reversed the unanimous decision of the FISA judges imposing limits on criminal prosecutors' role in FISA investigations and also ruled that the USA PATRIOT

78. See United States v. Moussaoui, 333 F.3d 509 (4th Cir. 2003); Katherine Q. Seelye, War on Terror Makes for Odd Twists in Justice System, N.Y. TIMES, June 23, 2002, at A16.

79. United States v. Lindh, 227 F. Supp. 2d 565 (E.D. Va. 2002); Jane Mayer, Lost in the Jihad: Why Did the Government's Case Against John Walker Lindh Collapse?, NEW YORKER, Mar. 10, 2003, at 50.

80. Toni Locy, Moussaoui Clash Tests Future of Terror Trials, USA TODAY, July 21, 2003, at 2A; Susan Schmidt, Prosecution of Moussaoui Nears a Crossroad: Facing Demands for Witness Testimony, Government May Turn Suspect Over to U.S. Military, WASH. POST, Jan. 21, 2003, at A8.

81. Ashley v. Ridge, 288 F. Supp. 2d 662 (D.N.J. 2003); Uritsky v. Ridge, 286 F. Supp. 2d 842 (E.D. Mich. 2003); Bezmen v. Ashcroft, 245 F. Supp. $2 d 446$ (D. Conn. 2003); AlmonteVargas v. Elwood, No. 02-CV-2666, 2002 U.S. Dist. LEXIS 12387 (E.D. Pa. June 28, 2002).

82. N. Jersey Media Group, Inc. v. Ashcroft, 308 F.3d 198 (3d Cir. 2002), cert. denied, 123 S. Ct. 2215 (2003).

83. 123 S. Ct. 2215 (2003). 
Act's expansion of FISA posed no Fourth Amendment problems. ${ }^{84}$ Again, the Supreme Court denied review. ${ }^{85}$

The Fourth Circuit in a later appeal in the Hamdi case essentially gave the government what the court earlier said it would not countenance - the power to detain without any meaningful judicial review. The Fourth Circuit upheld Hamdi's detention on the basis of nothing more than what it characterized as the "undisputed" fact that Hamdi had been captured on the battlefield abroad and refused to allow Hamdi to participate in the review. ${ }^{86}$ (The court did not explain how the circumstances of Hamdi's capture could be disputed or undisputed when Hamdi was unable to participate in the proceeding, and the lawyers representing his interests had no basis for knowing where he was captured).

And with the exception of the Ninth Circuit's decision in Gherebi, federal courts have refused even to consider habeas corpus petitions challenging the detention of foreign enemy combatants at Guantanamo Bay, although the Supreme Court has agreed to review the threshold jurisdictional question on whether the courts have any power to entertain the habeas claims. ${ }^{87}$

After the Awadallah decision, ${ }^{88}$ another judge in the same federal district ruled that the material witness statute was properly employed to detain witnesses to testify in grand jury proceedings and was not limited to criminal cases. ${ }^{89}$ The Court of Appeals for the Second Circuit subsequently reversed the lower court decision in Awadallah and reinstated the perjury charges against Awadallah. ${ }^{90}$

The Court of Appeals for the D.C. Circuit reversed the FOIA decision requiring disclosure of the names of the September 11th detainees, over a spirited dissent by Judge David Tatel. ${ }^{91}$ Finally, the federal courts have uniformly dismissed constitutional concerns raised by two Muslim charities whose assets have been frozen on vague

84. In re Sealed Case No. 02-001, 310 F.3d 717 (U.S. Foreign Intelligence Surveillance Ct. of Review 2002).

85. ACLU v. United States, 538 U.S. 920 (2003).

86. Hamdi v. Rumsfeld, 316 F.3d 450 (4th Cir. 2002), cert. granted, 124 S. Ct. 981 (2004).

87. See, e.g., Al Odah v. United States, 321 F.3d 1134 (D.C. Cir. 2003), cert. granted, 124 S. Ct. 534 (2003); Coalition of Clergy v. Bush, 310 F.3d 1153 (9th Cir. 2002), cert. denied, 123 S. Ct. 2073 (2003).

88. United States v. Awadallah, 202 F. Supp. 2d 17 (S.D.N.Y. 2002), rev'd 349 F.3d 42 (2d Cir. 2003).

89. In re the Application of the United States for a Material Witness Warrant, $213 \mathrm{~F}$. Supp. 2d 287 (S.D.N.Y. 2002).

90. Awadallah, 349 F.3d 42 (2d Cir. 2003).

91. Ctr. for Nat'l Sec. Studies v. U.S. Dep't of Justice, 331 F.3d 918 (D.C. Cir. 2003), cert. denied, 124 S. Ct. 1041 (2004). 
charges of support for terrorism under the International Emergency Economic Powers Act. ${ }^{92}$

It is too early to draw firm conclusions regarding the role of courts in the war on terrorism; we are, after all, still in the initial stages of this crisis, when courts are historically deferential, and the Supreme Court has not yet weighed in. The lower courts' greater willingness to challenge the government's national-security assertions may reflect the fact that the buck does not stop with those courts; any ruling against the government in this area is likely to be but one stop along the road to appeal. The Supreme Court was able to reach the result it did in Marbury in part because it left the President with nothing to defy, and thereby created the space to announce its doctrine of judicial supremacy. So, too, a district court decision on a matter of national security is unlikely to be the judiciary's last word, and therefore it may be easier for a district court to rule against the government's nationalsecurity assertions. The further up the appellate chain, the more likely a judicial decision will be determinative, and consequently, the more pressure judges may feel to uphold the government's actions.

Cultural factors may also play a role in the marginally increased willingness of courts to question the government's national-security initiatives. As Jack Goldsmith and Cass Sunstein have argued, President Bush's order authorizing military tribunals sparked a much more critical public reaction than did President Franklin Delano Roosevelt's use of military tribunals during World War II. ${ }^{93}$ They attribute the change to an increasing distrust of government in the wake of Vietnam and Watergate, and to a "massively strengthened commitment to individual rights" in our constitutional law. ${ }^{94}$

Without a doubt, the Vietnam era, and especially the revelations of FBI abuses targeted at antiwar and civil rights protesters during that period, effected a seismic shift in public and judicial attitudes toward executive power and national-security claims. ${ }^{95}$ Before Vietnam, J. Edgar Hoover was a national hero; today his name is shorthand for politically motivated government repression. The abuses of COINTELPRO, including extensive wiretapping of Dr. Martin Luther

92. See Holy Land Found. for Relief \& Dev. v. Ashcroft, 219 F. Supp. 2 d 57 (D.D.C. 2002), aff d, 333 F.3d 156 (D.C. Cir. 2003); Global Relief Found., Inc. v. O'Neill, 207 F. Supp. 2d 779 (N.D. Ill. 2002), aff'd, 315 F.3d 748 (7th Cir. 2002), cert. denied sub nom. Global Relief Found., Inc. v. Snow, 124 S. Ct. 531 (2003).

93. Jack Goldsmith \& Cass R. Sunstein, Military Tribunals and Legal Culture: What a Difference Sixty Years Makes, 19 CONST. COMM. 261 (2003).

94. Id. at 282.

95. See generally SUPPLEMENTARY DETAILED STAFF REPORTS ON INTELLIGENCE ACTIVITIES AND THE RIGHTS OF AMERICANS, BOOK III, FINAL REPORT OF THE SELECT COMM. TO STUDY GOVERNMENTAL OPERATIONS WITH RESPECT TO INTELLIGENCE ACTIVITIES, S. REP. NO. 94-755 (1976); FRANK DONNER, THE AGE OF SURVEILlaNCE: THE AIMS AND METHODS OF AMERICA'S POLITICAL INTELLIGENCE SYSTEM (1980). 
King, Jr., infiltration and disruption of lawful political organizations through "dirty tricks," secret warrantless searches, and the compiling of extensive records on the Bureau's critics, all undertaken under the rubric of "national security," have given the public and the media good reason to be skeptical about assertions of unchecked executive power.

Significantly, the Supreme Court itself took part in that transformation, as it permitted the publication of the Pentagon Papers, ${ }^{96}$ held unconstitutional warrantless "domestic security" wiretaps, ${ }^{97}$ and rejected President Nixon's broad assertions of executive privilege in connection with the Watergate prosecutions. ${ }^{98}$ In each of these cases, the Court stood up to the government, and its public reputation was enhanced as a result. That experience may well play a role in the courts' apparently greater willingness to challenge the government in the current era. ${ }^{99}$

A third factor may be the dramatically increased presence of human rights, civil rights, civil liberties, and immigrants' rights groups. During the Cold War, for example, the American Civil Liberties Union, the organization one might expect to be defending the Communists, was busy purging itself of Communists. ${ }^{100}$ The National Lawyers Guild was one of the few legal organizations to defend Communists' rights, and the Attorney General and the Director of the FBI targeted it as a Communist front organization for its efforts. ${ }^{101}$

Today, by contrast, the ACLU has been a vigorous defender of civil liberties, and it stands among a broad spectrum of organizations and institutions that have spoken out for the need to respect civil liberties in the war on terrorism. These include human rights organizations such as Amnesty International, Human Rights Watch, and the Lawyers' Committee for Human Rights; civil liberties and civil rights groups such as the Center for Constitutional Rights, the National Lawyers Guild, the National Committee to Protect Political Freedom, and the Center for National Security Studies; immigrants' rights and ethnicity-based groups such as the American-Arab

96. New York Times Co. v. United States, 403 U.S. 713 (1971).

97. United States v. U.S. District Court, 407 U.S. 232 (1972).

98. United States v. Nixon, 418 U.S. 683 (1974).

99. Coincidentally, the district court judge who initially barred the use of "domestic security" wiretaps, Judge Damon Keith, also wrote the decision for the Court of Appeals for the Sixth Circuit declaring unconstitutional John Ashcroft's blanket closure of immigration hearings.

100. See SAmuel Walker, In Defense of American Liberties: A History of THE ACLU 173-216 (1990).

101. Id. at 177, 264-65; see also ROBERT JUSTIN GOLDSTEIN, POLITICAL REPRESSION IN MODERN AMERICA: From 1870 TO THE PRESENT 364 (1978); ATHAN G. THEOHARIS \& John Stuart Cox, The Bull: J. Edgar hoOver and the Great american INQUISITION 218-19 (1988). 
Anti-Discrimination Committee, the American Immigration Lawyers' Association, the Asian American Legal Defense Fund, the National Immigration Forum, and the Japanese American Citizens League; grassroots organizing groups such as the Bill of Rights Defense Committees; religious groups such as the Muslim Public Affairs Council and the Council on American Islamic Relations; electronic privacy-focused groups such as the Center for Democracy and Technology and the Electronic Privacy Information Center; and libertarian organizations such as the Cato Institute. Most of these groups did not even exist during the Cold War. Their active and vocal presence today creates opportunities for grassroots involvement and education; generates reports and press releases on civil liberties abuses; gives voice to those who would otherwise be voiceless; and brings both domestic and international media attention to the government's excesses. ${ }^{102}$ That in turn affects the broader culture of concern about rights, which may lead courts to be more attentive than they might otherwise be to concerns on the liberty side of the securityliberty balance.

In short, while courts remain no panacea, we ought not dismiss them too quickly, as they have the potential to play a critical role in checking emergency powers.

\section{AN UNTIMELY PROPOSAL}

Despite these developments, some commentators have recently argued that the Constitution and, by extension, the courts ought not play much of a role at all in restricting the government's emergency powers. Professors Oren Gross and Mark Tushnet have each proposed that in light of the failure of constitutional constraints to limit executive action during emergencies, it might be better to recognize explicitly the validity of extraconstitutional measures during emergencies, or put differently, to acknowledge that emergency powers are not governed by the Constitution. ${ }^{103}$ Both do so in large part to avoid tainting

102. One initiative in particular has appeared to be especially influential. Soon after the USA PATRIOT Act was enacted, the Bill of Rights Defense Committee formed to pursue a grassroots strategy of getting local towns and counties to adopt resolutions condemning the civil liberties abuses of the Patriot Act. As of February 2004, 242 jurisdictions had adopted such resolutions, including three states - Hawaii, Alaska, and Vermont - and several major cities, including Chicago, Philadelphia, Detroit, Baltimore, San Francisco, and Albuquerque. See Bill of Rights Def. Comm., http://www.bordc.org (last updated Feb. 6, 2004). The initiative appears to have shifted public views toward the Patriot Act, prompting the Attorney General to launch an unprecedented speaking tour to seek to defend the Act. See David Cole, On the Road with Ashcroft, NATION, Sept. 22, 2003, at 22.

103. Gross, supra note 14; Tushnet, supra note 14. Professor George Alexander before them made a similar argument, contending that because courts perform poorly in emergencies, they should not get involved at all, and "redress must be achieved politically if it is to be effective." George J. Alexander, The Illusory Protection of Human Rights by National Courts During Periods of Emergency, 5 HuM. RTs. L.J. 1, 27, 65 (1984). 
constitutional law for ordinary times with decisions rendered on the exercise of emergency authorities. Justice Jackson warned of precisely such danger in his dissent in Korematsu. He maintained that as threatening to liberty as the military order establishing Japanese internment was, "a judicial construction of the due process clause that will sustain this order is a far more subtle blow to liberty than the promulgation of the order itself." ${ }^{104} \mathrm{He}$ reasoned that the military order would last only so long as the emergency and could be lifted by a subsequent commander, but that

once a judicial opinion rationalizes such an order to show that it conforms to the Constitution, or rather rationalizes the Constitution to show that the Constitution sanctions such an order, the Court for all time has validated the principle of racial discrimination in criminal procedure and of transplanting American citizens. ${ }^{105}$

Justice Jackson's proposal was in fact far more modest than his critique. He argued that the civil courts ought not play a role in enforcing military orders. ${ }^{106}$ Korematsu's case arose from a criminal prosecution in civil court for violating the military's exclusion order, and Justice Jackson would have reversed the conviction on the ground that civilian courts ought not dirty their hands with the military's business. But Jackson's proposal is as ineffectual as it is modest. It would have resolved Korematsu's case, but it would not have removed civilian courts from the business of reviewing the legality of military detention. Other detainees might well have filed habeas corpus actions challenging the validity of their detention. Unless Justice Jackson was prepared to say that the courts could unilaterally suspend the writ of habeas corpus for any military detention, he could not have avoided the necessity of passing judgment on the military's actions.

Mark Tushnet, in a thoughtful article provocatively titled Defending Korematsu?, ${ }^{107}$ cites Jackson's observations but takes them one step further. Not content with Jackson's prescription, Tushnet argues much more broadly for affirmative recognition of extraconstitutional emergency powers: "it is better to have emergency powers exercised in an extraconstitutional way, so that everyone understands that the actions are extraordinary, than to have the actions rationalized away as consistent with the Constitution and thereby normalized." 108 In his view, this is justified in order "to avoid normalizing the exception." 109

104. Korematsu v. United States, 323 U.S. 214, 245-46 (1944) (Jackson, J., dissenting).

105. Id. at 246 (Jackson, J., dissenting).

106. Id. at 247 (Jackson, J., dissenting).

107. Tushnet, supra note 14.

108. Id. at 306.

109. Id. at 307 . 
Oren Gross advocates a similar approach in much more detail in Chaos and Rules: Should Responses to Violent Crises Always Be Constitutional ${ }^{110}$ Gross contends, like Tushnet, that as a matter of reality we should candidly acknowledge that executive officials in times of crisis will act extraconstitutionally, and that we should do so in order to avoid "contaminat[ing]" the ordinary legal system with emergency powers." ${ }^{11}$ Gross would "inform public officials that they may act extralegally when they believe that such action is necessary for protecting the nation and the public in the face of calamity provided that they openly and publicly acknowledge the nature of their actions." 112 Because on this view extralegal authority is expressly permitted, the courts would not play a role in restraining such authority. Instead, it would "be up to the people to decide, either directly or indirectly (e.g., through their elected representatives in the legislature), how to respond to such actions." ${ }^{113}$ Like Tushnet, Gross insists that his approach is aimed at "the preservation of the constitutional order and of its most fundamental principles and tenets." $114 \mathrm{He}$ argues that the requirement that officials seeking to exercise such powers must act openly in defiance of the law and throw themselves on the judgment of the people would serve as an important deterrent to executive abuse of emergency powers.

These proposals are misguided. While I share to some extent the authors' skepticism about the ability of courts to protect the individual rights of those before them in national-security emergencies, both authors ignore the long-term benefits that judicial decisions in the national-security area have had in narrowing the range of rightsviolative options available to the government in the next emergency. Were courts to adopt the Gross-Tushnet notion that extraconstitutional measures are appropriate during emergencies, and that the only real check is political, much would be lost and little gained in the protection of civil liberties.

I would hesitate to adopt the Gross-Tushnet position for several reasons. First, it is predicated on a distinction between "emergency" periods and "normal" periods that, as Gross himself has convincingly shown, simply cannot be maintained. As Gross argues, "the belief in our ability to separate emergency from normalcy, counter-terrorism measures from the ordinary set of legal rules and norms," is a dangerous illusion. ${ }^{115}$ The United States has been under one state of emer-

110. Gross, supra note 14 .

111. Id. at 1133.

112. Id. at 1023 .

113. Id.

114. Id. at 1024.

115. Gross, supra note 14 , at 1022, 1069-96. 
gency or another since 1933; by the mid-1970s, there were more than 470 "emergency" laws on the books. ${ }^{116}$ Israel has been under an emergency regime since it was established as a state more than fifty years ago. ${ }^{117}$ And Great Britain has been under a state of emergency for most of the last thirty years, occasioned first by the IRA and later by the attacks of September 11th. ${ }^{118}$ Thus, emergency powers have a way of surviving long after the emergency has passed, and emergencies themselves may last decades. Emergency measures adopted in the United States today are especially likely to be long-lasting, given the nature of the war on terrorism, which is more like the war on drugs than a traditional war between nations. ${ }^{119}$ When Donald Rumsfeld was asked when the war on terrorism would be over (and therefore when the Guantanamo enemy combatant detainees would be freed), he answered that the war would not be over until there were no longer any "effective global terrorist networks functioning in the world." 120 Vice President Richard Cheney has been even more candid, arguing that we should consider the current period not an emergency at all, but "the new normalcy." 121

If the line between emergency and normal is evanescent, a doctrine of extraconstitutional authority cannot be safely cabined to emergency times. Far from protecting the Constitution in normal times, then, a doctrine expressly authorizing extralegal actions during emergencies would be at least as likely to contaminate the norm by expanding the realm of available government measures across the board as would insistence on a continuing role for courts and the Constitution in checking emergency and nonemergency government action.

Second, the Gross-Tushnet proposal to acknowledge extraconstitutional power would be likely to undermine the protection of rights

116. Glenn E. Fuller, Note, The National Emergency Dilemma: Balancing the Executive's Crisis Powers with the Need for Accountability, 52 S. CAL. L. REV. 1453, 1453 (1979). When the Senate considered a balanced budget amendment in 1995, Senator Howell Heflin proposed a "national security" exception and implied that it would have been appropriately invoked some 200 times in the 220 years of the republic. See Theodore P. Seto, Drafting a Federal Balanced Budget Amendment That Does What It Is Supposed to Do (and No More), 106 Yale L.J. 1449, 1533 (1997).

117. Gross, supra note 14, at 1073.

118. Id. at 1074 .

119. Tushnet concedes that the war on terrorism is more like a "condition" than an "emergency," but he does not explain how or even whether judges in his model would distinguish between the two. See Tushnet, supra note 14, at 297.

120. News Transcript, Dep't of Defense News Briefing: Secretary Rumsfeld and General Myers (Mar. 28, 2002), available at http:/www.defenselink.mil/ transcripts/2002/ t03282002 _t0328sd.html.

121. Lynn Ludlow, Paper Tigers, S.F. ChroniCle, Nov. 4, 2001, at C2; Bob Woodward, CIA Told To Do "Whatever Necessary" to Kill Bin Laden; Agency and Military Collobarating at "Unprecedented" Level; Cheney Says War Against Terror "May Never End," WaSH. PoST, Oct. 21, 2001, at A1. 
during emergencies (and by extension, during normal times that officials call emergencies). Gross claims that his proposal would have a salutary deterrent effect on official abuse of emergency powers, because officials could never be certain that their actions would in fact be ratified after the fact. And he argues that shifting the locus of justification and judgment from the judiciary to a political forum - the people or their elected representatives - would avoid the problem identified by Justice Jackson of formally authorizing emergency measures through judicial approval.

There are substantial reasons, however, to doubt both of Gross's claims. Even if acknowledging the legitimacy of extralegal measures would avoid formal judicial approval, it would not avoid the creation of less formal precedents that could be pointed to later to justify further incursions on liberties. The post hoc political rationalization process that Gross envisions, while lacking the attributes of the formal legal process, would nonetheless generate a more informal common law of extralegal emergency authorities. Once the political process has ratified a particular extralegal emergency action, officials will be able to point to that precedent as justification for their own subsequent actions. "Illegal" measures deemed permissible after the fact will no longer be clearly illegal, so long as a subsequent emergency can be analogized to the emergency found to warrant the illegal action previously. ${ }^{122}$

Nor is it clear that the Gross-Tushnet proposal would have the effect of avoiding formal judicial approval of emergency measures. Even if we were to adopt such a scheme, public officials would be exceedingly unlikely to admit that their actions were extralegal. Rather, they would almost invariably argue first that their measures were constitutional and argue only in the alternative that their actions were justified even if illegal. ${ }^{123}$ As a result, courts would continue to have to address the legality of emergency measures, and the drive to accommodate the Constitution to emergency conditions would continue to exert pressure on constitutional jurisprudence. Given the open-ended character of the Constitution and the fact that few of the liberties it protects are absolute, there will rarely be an emergency measure that government lawyers cannot defend with some constitu-

122. The 1988 statute offering restitution and an apology to the victims of the Japanese internment program suggests that at some point the political process may repudiate prior emergency measures. But that is almost certainly the exception that proves the rule. It took forty years to achieve and came only after the federal courts had themselves repudiated the convictions arising from the exclusion and internment programs. See supra note 26. Had the political process been asked to ratify the internment at the time, or in the decade or so that followed it, there is no evidence to suggest the result would have been repudiation rather than ratification.

123. See FINN, supra note 54, at 9 (1991) ("Even public officials who propose action that is arguably extraconstitutional typically seek to justify their actions on constitutional grounds."). 
tional argument. And while an open acknowledgment of the propriety of extralegal measures might reduce the hydraulic forces inducing courts to uphold emergency actions, the extent to which this would "save" normal constitutional law or deter abuse of emergency powers seems likely to be minimal. For the reasons stated above, courts would presumably still be reticent to rule against the government in emergency periods. And the open acknowledgment of the validity of extraconstitutional authority would seriously undercut the force of judicial decisions that now constrain emergency measures.

From the standpoint of deterring the abuse of emergency authority, the Gross-Tushnet proposal is not very different from what already exists. If a government official today adopts an extraconstitutional response to an emergency and his actions are later declared unconstitutional, he may in theory be subject to civil or criminal sanctions. But the likelihood that criminal or civil sanctions will be imposed is, in fact, virtually nil, and in any event the state nearly always indemnifies its officials from such liability. ${ }^{124}$ Moreover, such an official could always seek political post hoc ratification, in the form of immunity or indemnity from Congress or a pardon from the President. Thus, under the status quo, elected officials who act extraconstitutionally already face some, albeit limited, risk of liability, and have some political recourse to avoid liability.

Third, there is little reason to trust the political process to do the job of judging that Gross and Tushnet would assign to it. The real difference under a Gross-Tushnet approach would be that the principal job of judging emergency measures would presumptively fall not on the courts but on the political process. But this seems the most dubious aspect of the proposal. If courts are not particularly reliable in imposing limits on executive action during emergencies, the political process would almost certainly be worse. As Gross himself argues, the public and their elected representatives are especially prone to overreaction during times of crisis. ${ }^{125}$ The public is easily scared, and quick to approve of security measures launched in its name, especially if the measures do not directly affect the rights of the majority. Their elected representatives know that, and vote accordingly. Indeed, the very reason that we adopted a Constitution was that we understood that the people and their representatives would be tempted to violate basic principles in times of stress. In the words of Senator John Stockton in 1871: "Constitutions are chains with which men bind themselves in

124. Cornelia T.L. Pillard, Taking Fiction Seriously: The Strange Results of Public, Officials' Individual Liability Under Bivens, 88 GEO. L.J. 65 (1999) (critiquing the breadth of immunity doctrines and noting that indemnification of government officials is nearly universal).

125. Gross, supra note 14 , at $1035-42$. 
their sane moments that they may not die by a suicidal hand in the day of their frenzy." 126

Moreover, emergency measures almost always selectively target vulnerable groups and individuals, and foreign nationals in particular, making the political process an especially unreliable check on emergency powers. ${ }^{127}$ This fact apparently does not concern Tushnet; ${ }^{128}$ but for those concerned with the human rights of the most vulnerable, proposals that point to political rather than judicial processes for assessing the validity of emergency measures are fatally flawed.

Finally, Gross and Tushnet's proposal rests on the conventional wisdom that courts cannot be trusted to perform well in times of crisis. But the real question to be asked when assessing the courts' performance is: Compared to what? The courts are undoubtedly highly imperfect; but the alternatives are worse. One cannot rely on the executive branch to police itself in times of crisis. As Francis Biddle, Franklin Delano Roosevelt's Attorney General, candidly acknowledged, "The Constitution has not bothered any wartime President." 129 Executive officials after September 11th knew that they would take a much bigger "hit" politically if there were another terrorist act than if they locked up thousands of foreign nationals unconnected to terrorism. In such periods, executive officials ask for untrammeled authority, and assure the public that they will not abuse it. History shows that such trust is not warranted.

Congress is also unlikely to be a guardian of civil liberties. Its overwhelming approval of the Smith $\mathrm{Act}^{130}$ and the Internal Security Act $^{131}$ during the McCarthy era and of the Antiterrorism and Effective Death Penalty $\mathrm{Act}^{132}$ and the Patriot $\mathrm{Act}^{133}$ in the current era, coupled with its appropriation of funds for the Japanese internment in World

126. Cong. Globe, 42d Cong., 1st Sess. 574 (1871).

127. Cole, Enemy Aliens, supra note 12; David Cole, Enemy Aliens, 54 Stan. L. REV. 953 (2002); Gross, supra note 14, at 1037, 1082-85.

128. Tushnet, supra note 14, at 296-97 (arguing that the Justice Department's selective targeting of Arab and Muslim foreign nationals for questioning, secret detentions and trials, and selective deportation "does not seem to be a violation of civil liberties," and if so, are only "violations of the rights of residents who are not U.S. citizens"). In my view, these actions violated a wide range of constitutional rights, and the fact that they specifically affected foreign nationals, the most vulnerable and voiceless among us, only exacerbates the wrongs. See generally COLE, ENEMY ALIENS, supra note 12.

129. FRANCIS BIDDLE, IN BRIEF AUTHORITY 219 (1962).

130. Alien Registration Act, Pub. L. No. 76-670, 54 Stat. 670 (1940).

131. Internal Security Act of 1950, Pub. L. No. 81-831, 64 Stat. 987.

132. Antiterrorism and Effective Death Penalty Act of 1996, Pub. L. No. 104-132, 110 Stat. 1214.

133. Uniting and Strengthening America by Providing Appropriate Tools Required to Intercept and Obstruct Terrorism (USA PATRIOT) Act of 2001, Pub. L. No. 107-56, 115 Stat. 272. 
War II, illustrate that legislators are exceedingly unlikely to stand up against executive power in the name of civil liberties during emergencies. The need to be seen as "doing something" about the threat often translates into legislation that delegates sweeping powers to the executive branch.

Only the courts have an obligation to entertain claims of rights violations. The executive and legislative branches can simply choose to ignore such claims, and are likely to do so when those claims are not backed by substantial political power or influence. By contrast, assuming standing and justiciability, courts must adjudicate any claim that a government initiative violates constitutional rights. As a result, courts are often the only forum realistically available. For more than two years, the President has asserted the unilateral power to detain anyone he labels as an enemy combatant. Congress has done nothing to check or limit or even seriously address this assertion of power. The courts, by contrast, have addressed the question and issued multiple opinions, all of which are as of this writing headed for Supreme Court review.

To cite another example, over the past decade and a half, I have represented thirteen foreign nationals whom the government accused of having ties to terrorist organizations and sought to detain or deport using classified evidence that the foreign nationals had no opportunity to confront or rebut. ${ }^{134}$ The government maintained that the individuals' presence in the United States threatened national security, and that revealing the evidence that proved that contention would itself endanger national security. All thirteen were eventually released without undermining national security, but only when we challenged the government's actions in court as a violation of due process. Of the thirteen, twelve were Arab and/or Muslim. The thirteenth was a Kenyan woman married to a Palestinian and accused of being associated with a Palestinian organization.

What were our options in seeking to protect these individuals' constitutional rights? Congress would not help them. The issue of secret evidence in immigration proceedings had been raised in Congress, but far from providing a remedy, in 1996 Congress expressly expanded and authorized its use in a number of immigration settings. ${ }^{135}$ The executive branch was equally unresponsive. It was the executive branch, after all, that invoked the tactic in the first place. Even under the administration of President Bill Clinton, the executive branch was not a source of relief. And the public and the press, with a few exceptions, by and large paid little attention. When a court ordered an individual

134. See generally David Cole, Secrecy, Guilt by Association, and the Terrorist Profile, 15 J.L. \& RELIGION 267 (2000-2001).

135. Antiterrorism and Effective Death Penalty Act $\S 401$ (codified at 8 U.S.C. $\S 1531$ (2000)). 
released, its decision would often receive coverage in the print media. But I received countless phone calls from television news producers over the years looking for legal stories, all of whom ultimately determined that the secret evidence story would not sell because it involved foreign nationals rather than citizens. ${ }^{136}$ For my clients, it was court or nothing, court or more years of detention based on evidence they could not see. And to their credit, the courts were uniformly skeptical of the government's claims, and protective of the foreign nationals' right to see the evidence being used to deprive them of their liberty. ${ }^{137}$ Even immigration judges, who as administrative judges ultimately reviewable by the Attorney General lack the independence of the federal courts, were highly skeptical of the government's claims. ${ }^{138}$

Because courts are the only realistic option available to those targeted by emergency measures, and precisely because judges are all too human and already face substantial pressure to avoid fulfilling their responsibility, it seems especially misguided to advocate that they do so. The formal guarantees and ethical obligation of independence do not mean that judges are in fact always impartial and courageous, but the insistence that it is their obligation to be independent is critical to the enterprise of judging. We should not let judges off the hook when it comes to emergency matters, because they are the only real option for most persons targeted by emergency measures. As Fred Schauer has eloquently argued in a different setting, "The mere fact that courts will fold under pressure, however, does not dictate that they should be told that they may fold under pressure, because the effect of the message may be to increase the likelihood of folding even when the pressure is less." 139 Schauer continued, "Resisting the inevitable is not to be desired because it will prevent the inevitable, but

136. I am aware of only one exception. CBS's 60 Minutes covered the story of the government's use of secret evidence to deny entry to a group of Iraqis who had been involved in a failed CIA-backed coup attempt against Saddam Hussein, had been airlifted out of Iraq by the United States, but had then been determined at the border to have been double agents based on classified evidence. 60 Minutes: Unfinished Business: Six Iraqis Brought to the United States by the US Government for Help Against Saddam Hussein Are Imprisoned on Undisclosed Charges by the INS (CBS television broadcast, July 25, 1999). But it is likely that 60 Minutes' interest in the story stemmed as much from the identity of the Iraqis' pro bono lawyer - former CIA Director James Woolsey - as from their predicament.

137. See, e.g., American-Arab Anti-Discrimination Comm. v. Reno, 70 F.3d 1045, 1070 (9th Cir. 1995); Rafeedie v. INS, 880 F.2d 506, 512-13, 516 (D.C. Cir. 1989); Al Najjar v. Reno, 97 F. Supp. 2d 1329, 1356 (S.D. Fla. 2000), vacated on other grounds, 273 F.3d 1330 (11th Cir. 2001); Kiareldeen v. Reno, 71 F. Supp. 2d 402 (D.N.J. 1999).

138. See Cole, supra note 134 , at $272-75$. The immigration judges' skepticism suggests that relief was sometimes available within the executive branch. But it is significant that the relief came only from judges within the executive branch.

139. Frederick Schauer, May Officials Think Religiously, 27 WM. \& MARY L. REV. 1075,1084 n.11 (1986). 
because it may be the best strategy for preventing what is less inevitable but more dangerous." 140

In my view, the historical record does not demonstrate that courts will inevitably fold under the pressure of emergencies, but only that they will often do so. The historical developments reviewed above suggest that at least some judges may have learned from history to demand more narrowly tailored responses to emergencies. But more important, the record also shows that by exercising their responsibility to decide cases pitting individual rights against emergency executive power, the courts have over time developed rules that do constrain the executive in the next emergency. The danger of Gross and Tushnet's proposal is that we would be sacrificing even that for benefits that seem evanescent at best.

\section{CONCLUSION}

Courts, like every other institution of human governance, are imperfect. Tasked with the job of enforcing individual constitutional rights against the majority's will, judges remain prone to the same fears and anxieties that afflict us all during times of crisis. Thus, it should not be a surprise that courts have all too often deferred to unfounded assertions of government power on issues of national security; when the executive claims that the fate of the nation is at stake, it takes real courage to stand up to that assertion and subject it to careful scrutiny.

At the same time, the conventional wisdom that courts have failed during times of crisis is itself overstated. It is based both on a snapshot view of the courts' decisions, and on an overly idealized vision of what is in fact possible. When considered over time, courts have played a valuable role in reviewing and ultimately restraining some of the more egregious rights violations undertaken in the name of saving the country. Judicial decisions, while rarely providing relief to the initial victims of a crisis mentality, have played a role in restricting the options available to the government in the next emergency. Like Marbury $v$. Madison itself, these decisions may well be more important over the long run than their bottom lines would make them appear in the short run.

Given the salutary role that courts have played in enforcing constitutional limits on emergency responses, and given the paucity of credible alternatives, we should be reluctant to let judges off the hook. There seems to be little reason to trust the political branches to be more attentive to constitutional rights concerns than courts, even if courts themselves do not always perform as we might hope they 
would. As Eugene Rostow argued in assessing the Japanese internment cases shortly after they were decided, "It is hard to imagine what courts are for if not to protect people against unconstitutional arrest.... It is essential to every democratic value in society that official action taken in the name of the war power be held to standards of responsibility." 141

141. Eugene V. Rostow, The Japanese American Cases - A Disaster, 54 YALE L.J. 489, 511,514 (1945). 